\title{
Lifestyle and the risk of rheumatoid arthritis: cigarette smoking and alcohol consumption
}

\author{
J M W Hazes, B A C Dijkmans, J P Vandenbroucke, R R P de Vries, A Cats
}

\begin{abstract}
In a search for aspects of behaviour related to oral contraceptive use which might explain the favourable effect of oral contraception on the onset of rheumatoid arthritis (RA), cigarette smoking and alcohol consumption were studied as possible risk factors. Information on cigarette smoking and alcohol consumption was obtained by interview at the first visit to the outpatient clinic of 135 young women with confirmed definite or classical RA of recent onset and 378 control patients with soft tissue rheumatism or osteoarthritis. The diagnosis in all patients was confirmed by at least two years of follow up.

Of the patients with RA, $44 / 135$ (33\%) were current cigarette smokers compared with $181 / 378(48 \%)$ of the controls. The percentage of smokers among the controls was similar to that of women smokers in the general population. The adjusted risk of RA in women who smoked at least one cigarette a day was 0.61 ( $95 \%$ confidence interval (CI) 0.42 to 0.89 ). Thirty one (23\%) patients with RA and 137 (36\%) controls were alcohol drinkers. The risk of RA in women who consumed alcohol at least once a day was 0.52 (95\% CI 0.33 to $0.84)$. The low relative risk estimates for cigarette smoking and alcohol consumption were mutually independent and also independent of oral contraceptive use, the presence of the HLA-DR4 antigen, or a positive family history of RA.
\end{abstract}

The low incidence of alcohol consumption in the patients with RA might be due to the discontinuation of alcohol consumption after disease onset. The low incidence of cigarette smoking in the patients might reflect a protective effect of cigarette smoking on RA onset, possibly induced by changes in the immune system.

Conflicts in published reports about a possible protective effect of oral contraception on the onset of rheumatoid arthritis (RA) suggested that certain aspects of behaviour related to oral contraceptive use might be responsible for the reduction of RA. ${ }^{1}$ In some studies of oral contraception and the risk of $\mathrm{RA}$ smoking habits were found to be different in the patients with RA and their controls. ${ }^{2}$ Cigarette smoking is known to influence oestrogen related conditions such as osteoporosis, onset of menopause, and oestrogen dependent malignancies. ${ }^{4-6}$ It seems also to affect immune regulation. ${ }^{78}$ As RA is an immune mediated disease, probably modified by sex hormones, ${ }^{9}$ cigarette smoking might be a risk factor. Data of a case-control study, originally started to investigate the association between oral contraception and $R A$, were used to explore the relation between cigarette smoking and RA. Because we were interested in aspects of behaviour related to oral contraception we also looked at alcohol consumption.

\section{Patients and methods}

Details of the ascertainment of patients and controls are described in the original report. ${ }^{10}$ Patients and controls were drawn from all women attending the outpatient clinic for rheumatological disorders of the University Hospital in Leiden for the first time during the period 1982-1986. The age at first visit had to be between 20 and 50 years and onset of symptoms had to be within five years before the first visit. Patients were women with definite or classical RA according to the 1958 American Rheumatism Association criteria. The control group comprised women with soft tissue rheumatism or osteoarthritis. Detailed information was obtained by interview from 135 patients (response rate $98 \%$ ) and 378 controls (response rate $94 \%$ ). We obtained information on the number of cigarettes smoked daily and the daily number of alcohol consumptions at the time of the first visit. Further, we had information on the family history of RA, pregnancies, oral contraceptive use, menopause, and drug use.

There was a complete follow up of $96 \%$ of all patients and controls until 1987, which supported the consistency of the diagnosis.

Ninety nine per cent of the patients and $96 \%$ of the controls had been tissue typed for the HLA-DR4 antigen.

\section{ANALYSIS}

For the analysis we used exposure to cigarette smoking and alcohol consumption at the time of the first visit to the outpatient clinic. Crude odds ratios with $95 \%$ confidence limits were estimated according to Woolf. ${ }^{11}$ In case-control studies of diseases with a low incidence the odds ratio can be considered as a relative risk estimate. Simple stratification was performed for the variables year of birth, age at onset of symptoms, use of oral contraceptives before onset of symptoms, HLA-DR4, family history of $R A$, and-if not the exposure variablecigarette smoking or alcohol consumption. If there was an indication for effect modification the respective interaction term was entered in a logistic regression model and tested for signifi- 
cance with maximum likelihood ratio test statistics. The logistic regression model was also used to control simultaneously for confounders. The following variables we considered a priori to be of interest as potential confounders: year of birth, age at onset of symptoms, marital status, menopause, use of oral contraceptives before onset of symptoms, and-if not the exposure variable-cigarette smoking or alcohol consumption. All variables were entered in the model as continuous variables except oral contraceptive use and marital status, which were entered as categorical variables. Tests for linear trend were performed with the Mantel-Haenszel test. $^{12}$

\section{Results}

Table 1 shows the basic characteristics of patients and controls. The main differences between patients and controls were their smoking and drinking habits and their previous use of oral contraceptives. Patients less often used oral contraceptives before onset of symptoms and abstained more often from smoking and alcohol than controls. Some variation was found in the rest of the basic variables. Of the patients with RA, 44 (33\%) were current cigarette smokers compared with $181(48 \%)$ of the

Table 1 Characteristics of patients and controls. Number (\%) of patients is given

\begin{tabular}{|c|c|c|}
\hline Characteristic & $\begin{array}{l}\text { Patients } \\
(n=135)\end{array}$ & $\begin{array}{l}\text { Controls } \\
(n=378)\end{array}$ \\
\hline $\begin{array}{c}\text { Year of birth } \\
1932-1939 \\
1940-1944 \\
1945-1952 \\
1953-1966\end{array}$ & $\begin{array}{l}37(27) \\
29(21) \\
38(28) \\
31(23)\end{array}$ & $\begin{array}{r}91(24) \\
79(21) \\
107(28) \\
101(27)\end{array}$ \\
\hline $\begin{array}{l}\text { Age at symptom onset (years) } \\
16-20 \\
21-30 \\
31-40 \\
41-50\end{array}$ & $\begin{array}{l}3(2) \\
31(23) \\
47(35) \\
54(40)\end{array}$ & $\begin{aligned} & 11(3) \\
& 92(24) \\
& 147(39) \\
& 128(34)\end{aligned}$ \\
\hline $\begin{array}{l}\text { Marital status } \\
\text { Married } \\
\text { Unmarried } \\
\text { Widowed or divorced }\end{array}$ & $\begin{aligned} 107 & (79) \\
21 & (16) \\
7 & (5)\end{aligned}$ & $\begin{array}{r}294(78) \\
66(17) \\
18(5)\end{array}$ \\
\hline $\begin{array}{l}\text { Number of pregnancies } \\
0 \\
1-2 \\
\geqslant 3\end{array}$ & $\begin{array}{l}39(29) \\
53(39) \\
43(32)\end{array}$ & $\begin{array}{r}86(23) \\
153(40) \\
139(37)\end{array}$ \\
\hline $\begin{array}{l}\text { Menopausal status } \\
\text { Premenopausal } \\
\text { Postmenopausal } \\
\text { Smokers } \\
\text { Alcohol drinkers } \\
\text { Oral contraception use }\end{array}$ & $\begin{array}{r}120(89) \\
15(11) \\
44(33) \\
31(23)\end{array}$ & $\begin{array}{r}312(83) \\
66(17) \\
181(48) \\
137(36)\end{array}$ \\
\hline before symptom onset & $94(70)$ & $323(85)$ \\
\hline
\end{tabular}

Table 2 Relative risk of rheumatoid arthritis estimated for cigarette smoking at time of first visit to the outpatient clinic versus no smoking

\begin{tabular}{|c|c|c|}
\hline & $\begin{array}{l}\text { Crude odds } \\
\text { ratio } \\
(95 \% \mathrm{CI})\end{array}$ & $\begin{array}{l}\text { Adjusted } \\
\text { odds ratio* } \\
(95 \% \mathrm{CI})\end{array}$ \\
\hline $\begin{array}{l}\geqslant 1 \text { Cigarette/day } v \\
\text { no smoking } \\
1-10 \text { Cigarettes/day } v \\
\text { no smoking } \\
11-20 \text { Cigarettes/day } v \\
\text { no smoking } \\
\geqslant 21 \text { Cigarettes/day } v \\
\text { no smoking }\end{array}$ & $\begin{array}{l}0.53 \\
(0.35 \text { to } 0.80) \\
0.56 \text { to } 1.15) \\
(0.28 \text { to } 1.45 \text { o.45 } \\
0.26 \text { to } 0.86) \\
0.57 \text { to } 1.18) \\
(0.28 \text { ) }\end{array}$ & $\begin{array}{l}0.61 \\
(0.42 \text { to } 0.89) \\
0.60 \\
(0.33 \text { to } 1.08) \\
0.53 \text { to } 0.89) \\
(0.32 \text { to } \\
0.82 \\
(0.44 \text { to } 1.50)\end{array}$ \\
\hline
\end{tabular}

"Odds ratio calculated with a logistic regression model adjusted for year of birth, age at onset of symptoms, parity, alcohol consumptions (entered as continuous variables) and oral contraceptive use, marital status, menopause (entered as categorical variables). control women. The risk of RA in women who smoked at least one cigarette a day was considerably lower than in women who did not smoke-the relative risk estimate being about one half. Table 2 shows the crude and adjusted odds ratios. The odds ratio for $\geqslant 1$ cigarette a day changed only marginally from $0.53(95 \%$ confidence interval (CI) 0.35 to 0.80 ) to 0.61 (95\% CI 0.42 to 0.89 ) after adjusting for the potential confounders. Thus the effect of cigarette smoking on the development of RA was independent of the effect of oral contraceptive use. No trend was found for the number of cigarettes smoked daily (table 2).

Thirty one (23\%) patients and $137(36 \%)$ controls were alcohol drinkers. The relative risk of RA in women who had one or more alcohol consumptions a day was also close to one half (odds ratio $0.52,95 \%$ CI 0.33 to 0.84 ). The odds ratios adjusted for all potential confounders were almost the same as the crude odds ratios (table 3), indicating that the effect of alcohol consumption was independent of oral contraceptive use or cigarette smoking. Although the relative risk of RA was lower for high alcohol consumption than for moderate alcohol consumption, this trend was not significant $(p=0 \cdot 1)$. No interaction between cigarette smoking or alcohol consumption and all suggested effect modifiers (see 'Patients and methods') was found.

The percentages of current cigarette smokers among patients and controls were compared with the expected percentages in the general population (table 4). The percentages of cigarette smoking controls stratified by age group corresponded with the percentages of female smokers in the general population. Alcohol consumption could not be compared accurately because different ways of determining alcohol consumption have been used.

Table 3 Relative risk of rheumatoid arthritis estimated for alcohol consumption at time of first visit to the outpatient clinic versus no alcohol consumption

\begin{tabular}{|c|c|c|}
\hline & $\begin{array}{l}\text { Crude odds } \\
\text { ratio } \\
(95 \% \text { CI })\end{array}$ & $\begin{array}{l}\text { Adjusted } \\
\text { odds ratio* } \\
(95 \% \text { CI) }\end{array}$ \\
\hline $\begin{array}{l}\geqslant 1 \text { Alcohol } \\
\text { consumption/day } \\
v \text { none } \\
1-2 \text { Alcohol } \\
\text { consumptions/day } \\
v \text { none } \\
\geqslant 3 \text { Alcohol } \\
\text { consumptions/day } \\
v \text { none }\end{array}$ & $\begin{array}{l}0.52 \\
(0.33 \text { to } 0.84) \\
0.63 \\
(0.38 \text { to } 1.07) \\
0.28 \\
(0.11 \text { to } 0.72)\end{array}$ & $\begin{array}{l}0.54 \\
(0.35 \text { to } 0.82) \\
0.62 \\
(0.40 \text { to } 0.98) \\
0.31 \dagger \\
(0.13 \text { to } 0.74)\end{array}$ \\
\hline
\end{tabular}

*Odds ratio calculated with a logistic regression model adjusted for year of birth, age at onset of symptoms, parity, number of cigarettes (entered as continuous variables) and oral contracigarettes (entered as continuous variables) and oral contra-
ceptive use, marital status, menopause (entered as categorical ceptive use, $t p=0 \cdot 1$ for linear trend.

Table 4 Percentages of patients and controls smoking in the years 1982-1986 compared with the percentages in the general population in 1984*

\begin{tabular}{llll}
\hline $\begin{array}{l}\text { Age group } \\
\text { (years) }\end{array}$ & Patients & Controls & $\begin{array}{l}\text { General } \\
\text { population }\end{array}$ \\
\hline $19-24$ & 31 & 52 & 52 \\
$25-34$ & 34 & 57 & 55 \\
$35-49$ & 31 & 46 & 42 \\
\hline
\end{tabular}

*Percentages based on survey data from the Central Bureau of Statistics. 


\section{Discussion}

The original presumption that certain aspects of behaviour related to oral contraception might be responsible for a risk reduction of RA resulted in the surprising finding that cigarette smoking and alcohol consumption had a protective effect on the development of RA which was independent of oral contraceptive use. These risk factors were also mutually independent. The protective effect of cigarette smoking contradicts previous reports, in which an increased risk of RA among current smokers was suggested. ${ }^{23}$ Studies on alcohol consumption as a risk factor for RA have not been carried out as far as we know.

Our study was not primarily started with the intention of investigating cigarette smoking and alcohol consumption as possible risk factors. Therefore, we only obtained information about cigarette smoking and alcohol consumption at time of first visit and exact data on smoking and alcohol use at the time of the onset of symptoms were not recorded. The time interval between onset of symptoms and the first visit to the outpatient clinic was quite short (mean 1.5 years), however, and similar for patients and controls. Furthermore, patients and controls were women with comparable symptoms and most of them were only diagnosed during or after their first visit to the outpatient clinic. Although we had no information about discontinuation of smoking and drinking between the onset of symptoms and the first visit one would expect it to be similar in patients and controls in view of their comparability otherwise. Cigarette smoking was apparently not discontinued among the controls as shown by the fact that the percentage of smokers among the controls was similar to that of current smokers in the general population (table 4). The possibility cannot be excluded, however, that patients diagnosed by the family doctor as probable RA felt that smoking might contribute to their deterioration in health and therefore were more inclined to stop smoking than patients diagnosed as probably having soft tissue rheumatism or a degenerative condition. Although accurate comparison of alcohol consumption was not possible, we had the impression that the patients with RA and the controls used less alcohol than women in the general population. It is likely that alcohol consumption diminished or was stopped when treatment with drugs was started. At least $20 \%$ of the controls and up to $66 \%$ of the patients with RA were using pain killers regularly. Abstemiousness from alcohol in (male) patients with RA compared with osteoarthritic controls has been reported previously. ${ }^{13}$ This disparity in alcohol consumption seemed to be due to a striking increase in joint pain after drinking alcohol, fear of adverse drug reactions with alcohol, and a belief that 'alcohol and arthritis do not mix'.

The differences in smoking habits between patients and controls and therefore the possible protective effect of cigarette smoking on RA development seems a more acceptable finding in our study. The two studies which contradict our results for smoking also disagreed about the protective effect of oral contraceptive use in RA. ${ }^{2}$ Cigarette smoking is known to have antioestrogenic effects ${ }^{414}$ and therefore should counteract the immunomodulating activities of female hormones. Higher concentrations of the androgens dehydroepiandrosterone sulphate and androstenedione have been found in cigarette smokers than in non-smokers. ${ }^{15}$ Androgens can also suppress immune responses, ${ }^{16} 17$ which might explain the reduction of RA in smokers. Cigarette smoking may induce diverse changes in the immune system independent of hormonal pathways. ${ }^{78}$ In analogy with the smoking induced decrease of Langerhans' cells in the cervix with subsequent increase of cervical neoplasia, ${ }^{8}$ Spector and Blake suggested that reduction of the dendritic cells in the synovial membrane might lower the risk of RA. ${ }^{18}$

Although this study was not primarily started to investigate the association between cigarette smoking, alcohol consumption, and the onset of RA, the results seem to be sufficiently curious to warrant new studies on this subject.

The authors thank Mrs L Eichorn for technical assistance with computing and mailing and Mrs G M Th Schreuder and collaborators for the HLA typing. The manuscript was typed by Mrs J Ravensbergen. This work was supported by the Dutch Prevention Fund.

1 Female sex hormones and rheumatoid arthritis: Proceedings of an international workshop held at Leiden, the Nether lands, March 1989. Br ₹ Rhewematol 1989; 28 (suppl I): 1-73.

2 Hernandez-Avila M, Liang M, Willet W C, et al. Risk factors for the development of rheumatoid arthritis. Arthritis Rheum 1988; suppl 58: Abstract 121.

3 Vessey MP, Villard-Mackintosh L, Yeates D. Oral contraceptives, cigarette smoking and other factors in relation to arthritis. Contraception 1987; 35: 457-4.

4 Baron J A. Smoking and estrogen-related disease. Am $f$ Epidemiol 1984; 119: 9-22.

5 Daniell $\mathrm{H} \mathrm{W}$. Osteoporosis of the slender smoker: vertebral compression fractures and loss of metacarpal cortex in relation to postmenopausal cigarette smoking and lack of obesity. Arch Intern Med 1976; 136: 298-304.

6 Baron J A, Byers T, Greenberg E R, Cummings K M, Swanson $M$. Cigarette smoking in women with cancers of the breast and reproductive organs. Foumal of the National Cancer Institute 1986; 77: 677-80.

7 Miller L G, Goldstein G, Murphy M, Ginns L C. Reversible alterations in immunoregulatory $T$ cells in smoking. Analysis by monoclonal antibodies and flow cytometry. Chest 1982; 82: 526-9.

8 Barton S E, Jenkins D, Cuzick J, Maddox P H, Edwards R, Singer A. Effect of cigarette smoking on cervical epithelial immunity: A mechanism for neoplastic change? Lancet immunity: A me ii: $652-4$.

9 Persellin $R H$. The effect of pregnancy on rheumatoid arthritis. Bull Rherm Dis 1976; 27: 922-6.

10 Hazes J M W, Dijkmans B A C, Vandenbroucke J P, de Vries R R P, Cats A. Reduction of the risk of rheumatoid arthritis among women who take oral contraceptives. Arthritis Rheum 1990; 33: 173-9.

11 Woolf $\mathrm{B}$. On estimating the relation between bloodgroup and disease. Ann Hum Genet 1955; 19: 251-3.

12 Schlesselman J J. Case-control studies. New York: Oxford University Press, 1982.

13 Bradlow J A, Mowat A G. Alcohol consumption in arthritis patients: clinical and laboratory studies. Ann Rheum Dis 1985; 44: 163-8.

14 Michnovicz J J, Hershcopf R J, Naganuma H, Bradlow H L, Fishman $\mathrm{J}$. Increased 2-hydroxylation of estradiol as a possible mechanism for the anti-estrogenic eff.

15 Khaw K T, Tazuke S, Barrett-Connor E. Cigarette smoking and levels of adrenal androgens in postmenopausal women. and Engl $\mathcal{Y}$ Med 1988; 318: 1705-9.

16 Grossman C J. Regulation of the immune system by sex Grossman C J. Regulation of the immune

17 Ahmed S A, Penhale W J, Talal N. Sex hormones, immune Ahmed S A, Penhale W J, Talal N. Sex hormones, immune responses

18 Spector T D, Blake D R. Effect of cigarette smoking on Langerhans' cells. Lancet 1988; ii: 1028. 